\title{
Article \\ Phage PPPL-1, A New Biological Agent to Control Bacterial Canker Caused by Pseudomonas syringae pv. actinidiae in Kiwifruit
}

\author{
Yu-Rim Song ${ }^{1}$, Nguyen Trung Vu ${ }^{1}$, Jungkum Park ${ }^{1}$, In Sun Hwang ${ }^{1}$, Hyeon-Ju Jeong ${ }^{2}$, Youn-Sup Cho ${ }^{2}$ \\ and Chang-Sik Oh ${ }^{1,3, *(1)}$
}

check for

updates

Citation: Song, Y.-R.; Vu, N.T.; Park, J.; Hwang, I.S.; Jeong, H.-J.; Cho, Y.-S.; Oh, C.-S. Phage PPPL-1, A New Biological Agent to Control Bacterial Canker Caused by Pseudomonas syringae pv. actinidiae in Kiwifruit. Antibiotics 2021, 10, 554. https://doi.org/10.3390/

antibiotics 10050554

Academic Editor: Carla Pereira

Received: 13 April 2021

Accepted: 7 May 2021

Published: 10 May 2021

Publisher's Note: MDPI stays neutral with regard to jurisdictional claims in published maps and institutional affiliations.

Copyright: (C) 2021 by the authors. Licensee MDPI, Basel, Switzerland. This article is an open access article distributed under the terms and conditions of the Creative Commons Attribution (CC BY) license (https:// creativecommons.org/licenses/by/ $4.0 /)$.
1 Department of Horticultural Biotechnology, College of Life Science, Kyung Hee University, Yongin 17104, Korea; yulimy@khu.ac.kr (Y.-R.S.); nguyen12sh@gmail.com (N.T.V.); jungkuum@naver.com (J.P.); hongkong10@hanmail.net (I.S.H.)

2 Fruit Research Institute, Jeollanamdo Agricultural Research and Extension Services, Haenam-gun 59021, Korea; pob1256@korea.kr (H.-J.J.); aktis@korea.kr (Y.-S.C.)

3 Graduate School of Biotechnology, Kyung Hee University, Yongin 17104, Korea

* Correspondence: co35@khu.ac.kr; Tel.: +82-31-201-2678

\begin{abstract}
Pseudomonas syringae pv. actinidiae (Psa) is a Gram-negative bacterium that causes bacterial canker disease in kiwifruit. Copper or antibiotics have been used in orchards to control this disease, but the recent emergence of antibiotic-resistant Psa has called for the development of a new control agent. We previously reported that the bacteriophage (or phage) PPPL-1 showed antibacterial activity for both biovar 2 and 3 of Psa. To investigate the possibility of PPPL-1 to control bacterial canker in kiwifruit, we further tested the efficacy of PPPL-1 and its phage cocktail with two other phages on suppressing disease development under greenhouse conditions using 6 weeks old kiwifruit plants. Our results showed that the disease control efficacy of PPPL-1 treatment was statistically similar to those of phage cocktail treatment or Agrimycin ${ }^{\mathrm{TM}}$, which contains streptomycin and oxytetracycline antibiotics as active ingredients. Moreover, PPPL-1 could successfully kill streptomycin-resistant Psa isolates, of which the treatment of Buramycin ${ }^{\mathrm{TM}}$ carrying only streptomycin as an active ingredient had no effect in vitro. The phage PPPL-1 was further characterized, and stability assays showed that the phage was stable in the field soil and at low temperature of $0 \pm 2{ }^{\circ} \mathrm{C}$. In addition, the phage could be scaled up quickly up to $10^{10} \mathrm{pfu} / \mathrm{mL}$ at $12 \mathrm{~h}$ later from initial multiplicity of infection of 0.000005 . Our results indicate that PPPL-1 phage is a useful candidate as a biocontrol agent and could be a tool to control the bacterial canker in kiwifruit by Psa infection in the field conditions.
\end{abstract}

Keywords: bacterial canker; disease control; kiwifruit; phage; Pseudomonas syringae pv. actinidiae

\section{Introduction}

Bacterial canker caused by Psa has been considered as the most devastating disease in both Actinidia deliciosa (green kiwifruit) and Actinidia chinensis (yellow kiwifruit) [1-3]. The disease symptoms can occur on the various organs of kiwifruit plants such as red ooze on cane and trunk, dark brown spots with the yellowish halos on leaves, wilting vines, and necrosis in flowers $[4,5]$. Among them, the wide death of vines leads to the most economic loss [6]. The serious damage by Psa infection on the kiwifruit industry was reported in the major kiwifruit growing countries such as China, Italy, and New Zealand [7-10].

Psa was first isolated in Japan in 1984 [11], and sporadic outbreaks were reported in Korea [4,12], Portugal [13], Spain [14], France [15], Turkey [16], Slovenia [17], Greece [18], and Georgia [19]. Based on geographical, genetic, and biological characteristics, Psa strains can be grouped into biovars 1, 2, 3, 5, and 6 [20]. Biovar 4 was reclassified as P. syringae pathovar actinidifoliorum [21]. In Korea, several Psa strains belonging to biovar 2 were isolated from green kiwifruit cv. 'Hayward' (e.g., JYS5) and yellow kiwifruit cv. 'Hort16A' (e.g., KBE9) [4]. Biovar 3 strains, which was first isolated in Italy in 2008 [1], also appeared in 
Korea (e.g., SYS1) [22]. Recently, biovar 3 strains have been found in Europe, New Zealand, Chile, and China, resulting in severe damage in the international kiwifruit industry [23-25].

Currently, only a few effective therapeutic definitive methods are demonstrated for canker disease in kiwifruit. Copper or streptomycin products have been traditionally used [26], but Psa strains resistant to copper and streptomycin have been reported in several countries including Korea [27-29]. Moreover, continuous usage or environmental contamination with these chemicals significantly contributes to generation of resistant bacteria. Hence, alternatives methods to manage bacterial canker in kiwifruit are needed.

A phage is a virus that infects and kills host bacterial cells, and it is mostly species specific. It is not harmful to human and environment, thus it has been considered as an eco-friendly agent to control plant pathogenic bacteria, in particular, antibiotic-resistant pathogenic bacteria $[30,31]$. Phages have the self-replicating property and high host specificity. These characteristics make them promising as an alternative method to antibiotics for control of bacterial canker [32]. To control phytopathogenic bacteria, several phage-based products such as AgriPhage ${ }^{\mathrm{TM}}$ (Salt Lake City, UT, USA) have already been developed and commercialized, and many studies showing significant biocontrol efficacy of phages for the management of the several important phytopathogenic bacteria in recent years have been reported [33].

Although the large number of phages targeting to Psa were isolated and characterized [34-37], only a few of them such as Pseudomonas phage $\varphi 6$ were demonstrated to show their control efficacy ex vivo on bacterial canker [38]. We previously reported virulent phages, PPPL-1, KHU $\varphi 34$, and KHU $\varphi 38$, which could kill Psa strains belonging to both biovar 2 and 3 and other P. syringae pathovars [37,39]. PPPL-1 and KHU $\varphi 38$ belong to Podoviridae family, while KHU $\varphi 34$ is a member of Myoviridae family. Additionally, PPPL-1 genome analysis illustrated that it is a virulent phage with genes encoding a class II holin and Rz-like lysis protein, but no genes relating to lysogenic cycle [39]. Furthermore, this phage was stable under diverse environmental conditions where kiwifruit trees are growing. Thus, we aimed to further examine the potential of PPPL-1 phage in controlling bacterial canker disease in kiwifruit as well as in managing antibiotic-resistant Psa isolates. Furthermore, the combination of PPPL-1 with KHU $\varphi 34$ and $\mathrm{KHU} \varphi 38$ in controlling bacterial canker disease in kiwifruit was also evaluated.

\section{Results}

\subsection{Control Efficacy of PPPL-1 Phage to Prevent Bacterial Canker in Planta}

To test the control efficacy of PPPL-1 phage against bacterial canker in kiwifruit, $10^{8} \mathrm{pfu} / \mathrm{mL}$ of phages (equivalent to MOI 1.0) were first treated on both sides of 12 kiwifruit leaves of 5 plants under greenhouse conditions, followed by application of Psa KBE9 (biovar 2) and SYS1 (biovar 3) mixture $2 \mathrm{~h}$ after phage treatment. The PPPL-1 phage application significantly protected the treated leaves with Psa, based on the reduction in visible symptomatic spots compared to the untreated one (Figure 1a). Indeed, the number of visible symptomatic spots in the PPPL-1-pretreated leaves maintained at a lower rate around $16.7 \pm 4.63$ (mean \pm standard error) spots after 14 days after inoculation (dai), while it continuously increased and reached to an average of $512.9 \pm 144.35$ spots at 14 dai in the untreated leaves (Figure 1b). Furthermore, the disease incidence in the PPPL-1-pretreated leaves was not statistically different from that in leaves treated with commercial antibiotic product-Agrimycin $^{\mathrm{TM}}$ (approximately 41.7 spots \pm 16.83 ) (Figure $1 \mathrm{~b}$ ). These assays were repeated three times with the similar results. These results indicate that the pretreatment of PPPL-1 phage can efficiently control bacterial canker in kiwifruit as much as the treatment of the antibiotics product. 
(a)
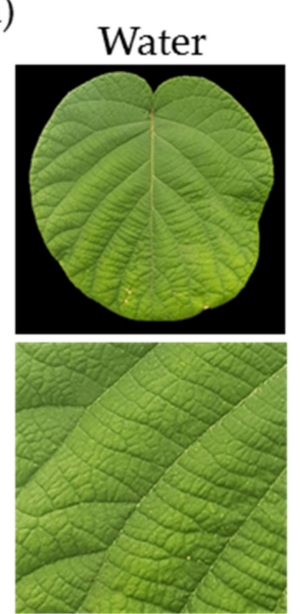
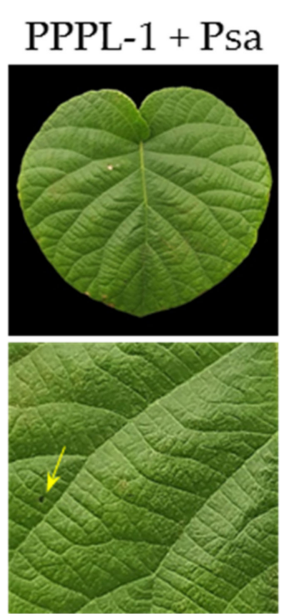

Agrimycin
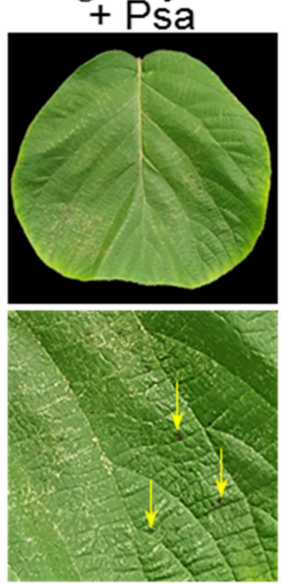

(b)

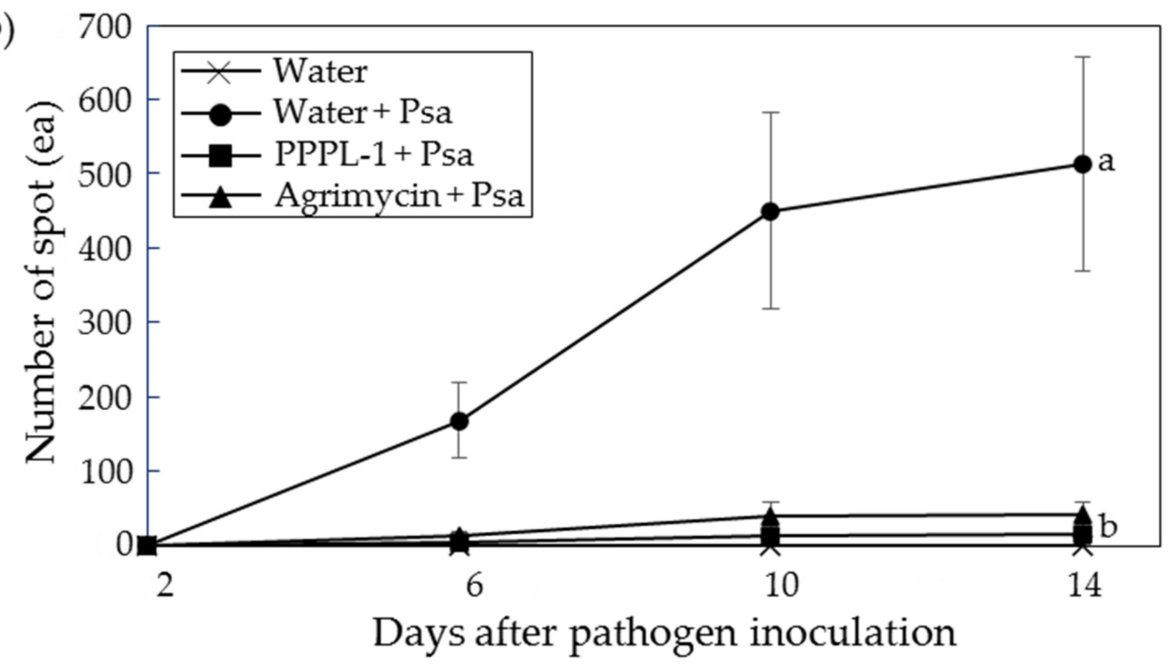

Figure 1. Control efficacy of PPPL-1 phage treatment against bacterial canker caused by Pseudomonas syringae pv. actinidiae (Psa) KBE9 and SYS1 mixture in planta. (a) The kiwifruit leaves 10 days after pathogen inoculation (dai) with phages or antibiotic pesticide. Bottom figures are enlarged photographs of top leaves. The yellow arrows indicate symptomatic spots. The sterilized water was used for dilution of phages and bacteria. Water, PPPL- $1\left(10^{8} \mathrm{pfu} / \mathrm{mL}\right)$, or $\operatorname{Agrimycin}^{\mathrm{TM}}(0.4 \mathrm{~g} / \mathrm{L})$ was applied $2 \mathrm{~h}$ before infection with Psa $\left(10^{8} \mathrm{cfu} / \mathrm{mL}\right)$. (b) The mean of numbers of symptomatic spots on the treated leaves $(n=12)$. The error bars indicate the standard error, and the different alphabets in the next of lines indicate the different groups based on significant differences at $p<0.05$ by Duncan's multiple range test at 14 dai.

Previously, we reported other Psa phages, $\mathrm{KHU} \varphi 34$ and $\mathrm{KHU} \varphi 38$, which belong to Myoviridae and Podoviridae, respectively, and their lytic activity against Psa SYS1 (biovar 3) was less than that against Psa KBE9 (biovar 2) in vitro [37]. Therefore, we tried to compare their control efficacy against Psa KBE9 and SYS1 mixture in planta. Consistently to the previous result, in the presence of Psa KBE9 infection, the individual treatment of $\mathrm{KHU} \varphi 34$ and $\mathrm{KHU} \varphi 38$ phages showed less effects compared to PPPL-1 in planta, but the phage cocktail with three phages showed the similar efficacy to PPPL-1 phage alone (Figure 2). While the leaves treated with Psa only showed an average of $512.9 \pm 144.35$ symptomatic spots at 14 dai, the leaves pretreated with $\operatorname{KHU} \varphi 34$ and KHU $\varphi 38$ showed $234.17 \pm 98.46$ and $428.33 \pm 112.15$ spots, compared with only $16.67 \pm 4.63$ and $27.08 \pm 10.16$ spots by pretreatment with PPPL- 1 and the phage cocktail, respectively (Figure 2 b). These assays were repeated twice with the similar results. Overall, these results indicate that the control efficacy of PPPL-1 phage is significantly similar to 
phage cocktail treatment and better than those of two other phages, consistent with in vitro lytic activity.

(a)
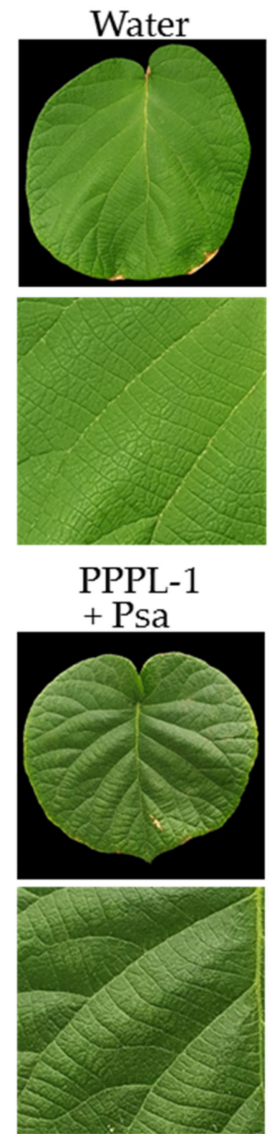
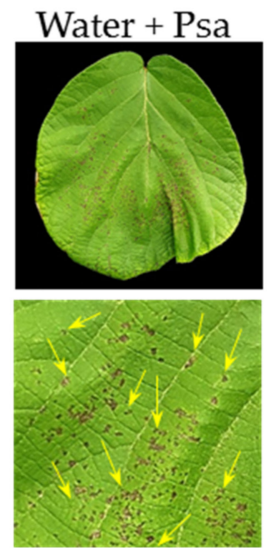

Phage cocktail
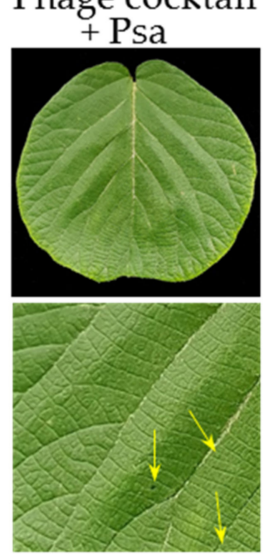
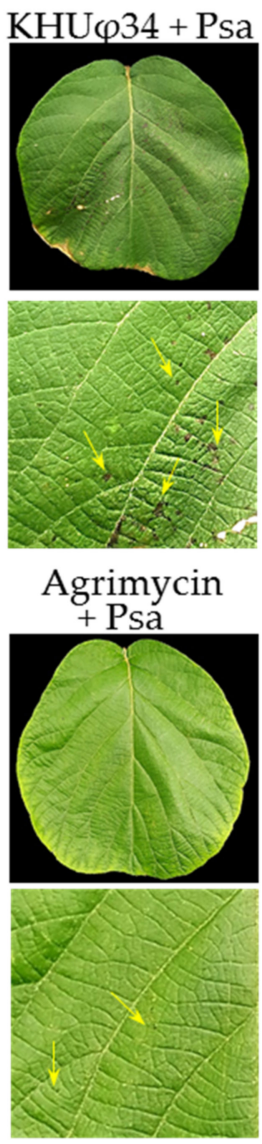
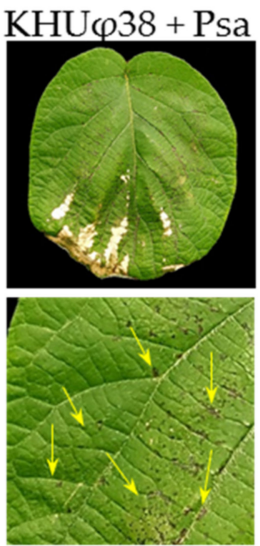

(b)

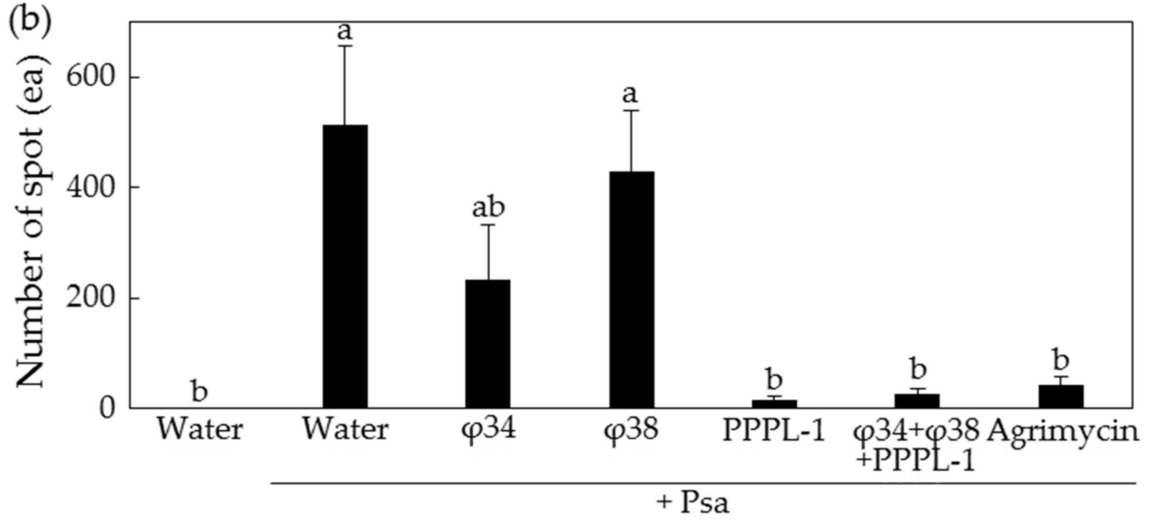

Figure 2. Control efficacy of PPPL-1 phage compared to $\operatorname{KHU} \varphi 34$, $\mathrm{KHU} \varphi 38$, or phage cocktail with all three phages against bacterial canker caused by Pseudomonas syringae pv. actinidiae (Psa) KBE9 and SYS1 mixture in planta. (a) The kiwifruit leaves 10 days after Psa inoculation (dai) with phages or antibiotic pesticide. Bottom figures of each treatment are enlarged photographs of top leaves. The yellow arrows indicate symptomatic spots. The sterilized water was used for dilution of phages and bacteria. Buffer, each phage $\left(10^{8} \mathrm{pfu} / \mathrm{mL}\right)$, or Agrimycin ${ }^{\mathrm{TM}}(0.4 \mathrm{~g} / \mathrm{L})$ was treated $2 \mathrm{~h}$ before treatment with bacterial suspension $\left(10^{8} \mathrm{cfu} / \mathrm{mL}\right)$. Mock and buffer are sterilized water. (b) The mean of number of symptomatic spots on the treated leaves $(n=12)$. The error bars indicate the standard error, and the different letters on top of each bar indicate the different groups based on significant differences at $p<0.05$ by Duncan's multiple range test at 10 dai. 


\subsection{Concentration and Treatment Timing of PPPL-1 Phage for Efficient Control of Bacterial Canker in Planta}

To examine if phage concentration could be reduced for disease control, the control efficacy of MOI 0.1 was compared with that of MOI 1.0 in 20 leaves of 5 plants under greenhouse conditions. While leaves treated with Psa KBE9 only showed $62.7 \pm 20.7$ spots 5 weeks after treatment, about $12.6 \pm 4.29$ and $27.1 \pm 7.29$ spots from MOI 1.0 and MOI 0.1 , respectively, were observed (Figure 3a). These assays were repeated twice with the similar results. These results indicate that, although both MOI treatments significantly reduced the disease severity by Psa in kiwifruit leaves, MOI 1.0 was more efficient, and it was statistically similar to Agrimycin ${ }^{\mathrm{TM}}$ treatment.

(a)

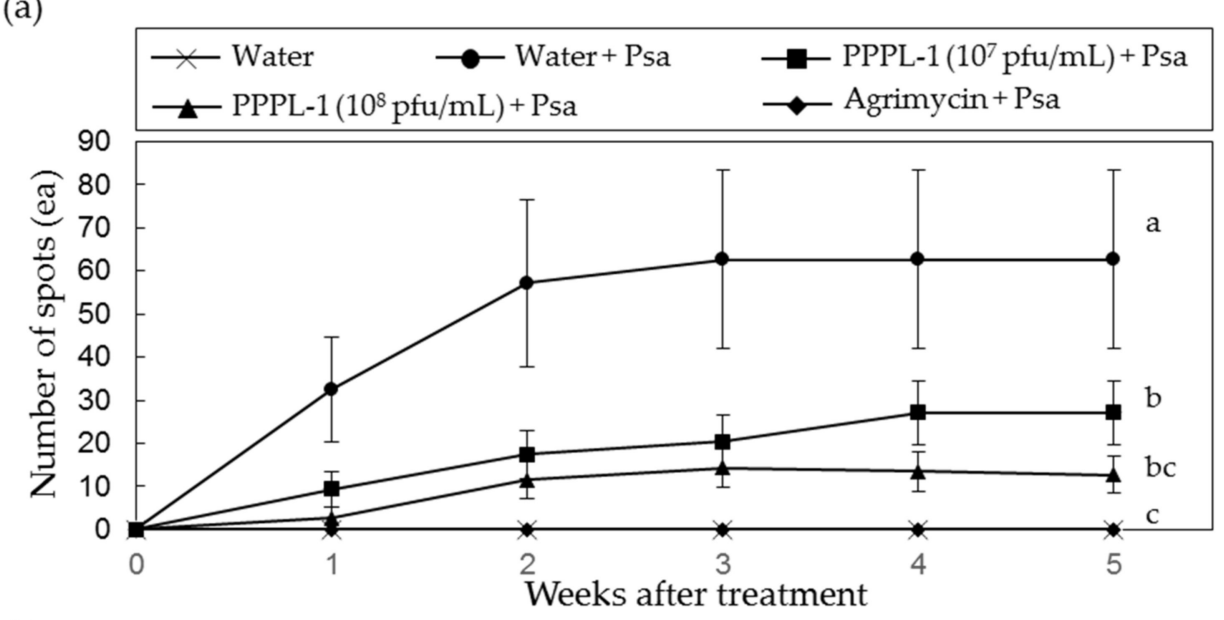

(b)

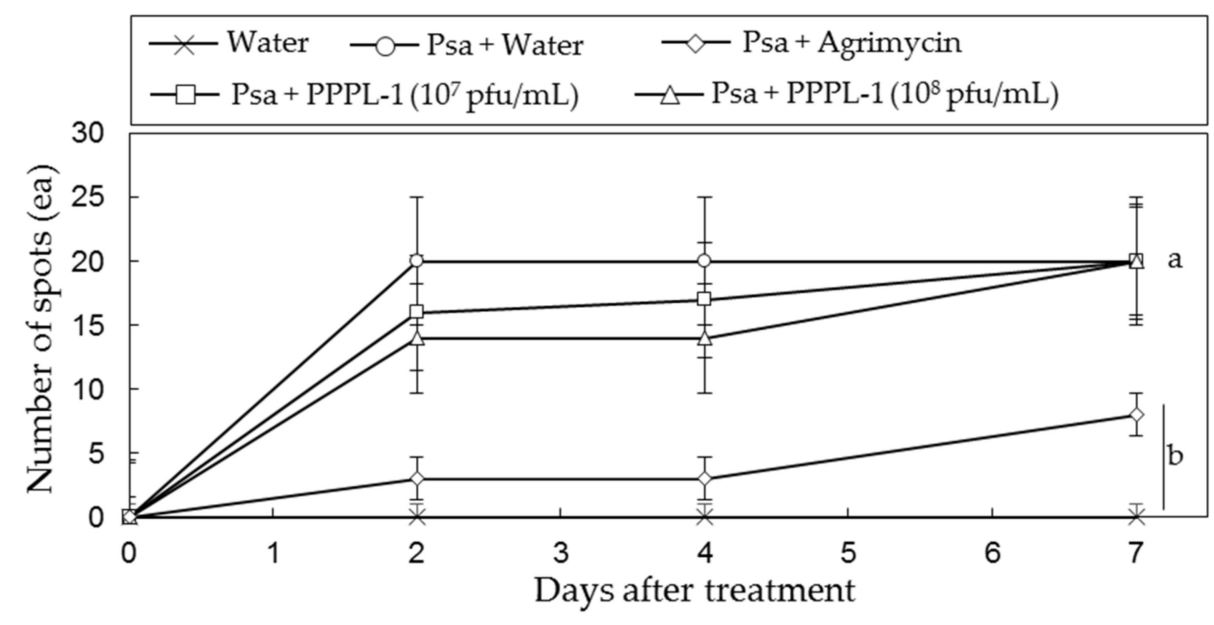

Figure 3. Effects of phage concentration and timing of phage treatment on control efficacy of PPPL-1 phage treatment against bacterial canker caused by Pseudomonas syringae pv. actinidiae (Psa) KBE9 in kiwifruit leaves. (a) Leaves were treated with phages at $10^{7}$ and $10^{8} \mathrm{pfu} / \mathrm{mL}$ by brushing on both sides of leaves, then Psa was applied on the same sides $2 \mathrm{~h}$ later. (b) Leaves were inoculated with Psa on both sides of leaves by brushing, then phages at $10^{7}$ and $10^{8} \mathrm{pfu} / \mathrm{mL}$ were applied on the same sides by brushing. The front treatment of each treatment label was first applied, and the back one was treated $2 \mathrm{~h}$ later. The error bars indicate the standard error $(n=20)$, and the different alphabets in the next of lines indicate the different groups based on significant differences at $p<0.05$ by Duncan's multiple range test at 5 weeks or 7 days after treatment.

In addition to the prophylactic efficacy of PPPL-1 phage, its therapeutic efficacy with MOI 1.0 was also examined. The plants were inoculated with Psa bacteria and then phages were applied $2 \mathrm{~h}$ later. As a result, the control efficacy of phage treatment on kiwifruit 
leaves after pathogen treatment exhibited statistically no difference from that of no phage treatment (Figure $3 b$ ). These results indicate no therapeutic efficacy of PPPL-1 phage for application in planta.

\subsection{Antibacterial Effects of PPPL-1 Phage on Streptomycin-Resistant Psa Isolates In Vitro}

Streptomycin-based products are mainly used for control of Psa [26,28]. However, many studies have reported the emergence of streptomycin-resistant Psa isolates [27,29,40]. Four streptomycin-resistant Psa strains isolated from South Korea (YCS3, JYS5, KACC10584, and KACC10595) were used to examine the antibacterial effects of PPPL-1 against them in vitro. For this assay, Buramycin ${ }^{\mathrm{TM}}$ containing a streptomycin as an active compound and Agrimycin ${ }^{\mathrm{TM}}$ containing both streptomycin and oxytetracycline as active compounds were used as controls. Buramycin ${ }^{\mathrm{TM}}$ did not suppress bacterial growth of streptomycin-resistant Psa isolates at all, while it caused the formation of clear zone against only Psa strain KBE9, a streptomycin-sensitive isolate (Figure 4a,b). In contrast, both Agrimycin ${ }^{\mathrm{TM}}$ and PPPL-1 phage formed clear zones against all Psa strains, and their antibacterial activities were statistically very similar at $p<0.05$, although the sizes of clear zones slightly varied among Psa isolates. These results indicate that PPPL-1 phage could be used to control streptomycin-resistant Psa isolates like antibiotics products.

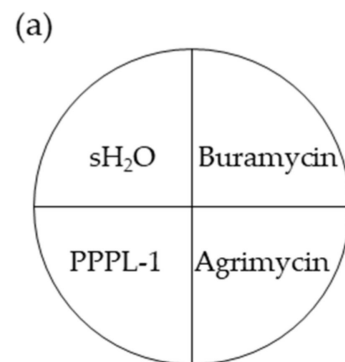

JYS5 $\left(\mathrm{STR}^{\mathrm{T}}\right)$

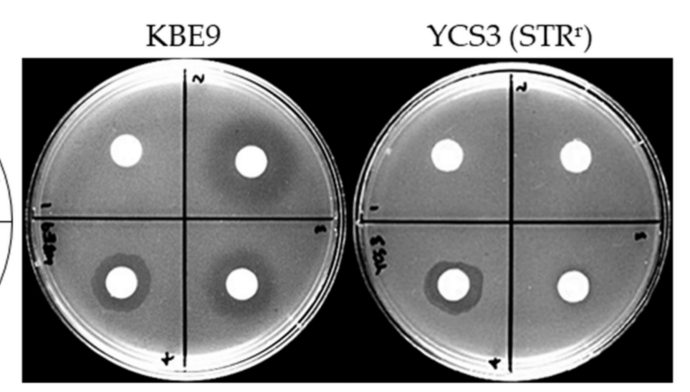

KACC10584(STR $\left.{ }^{\mathrm{r}}\right)$

$\mathrm{KACC} 10595\left(\mathrm{STR}^{\mathrm{r}}\right)$

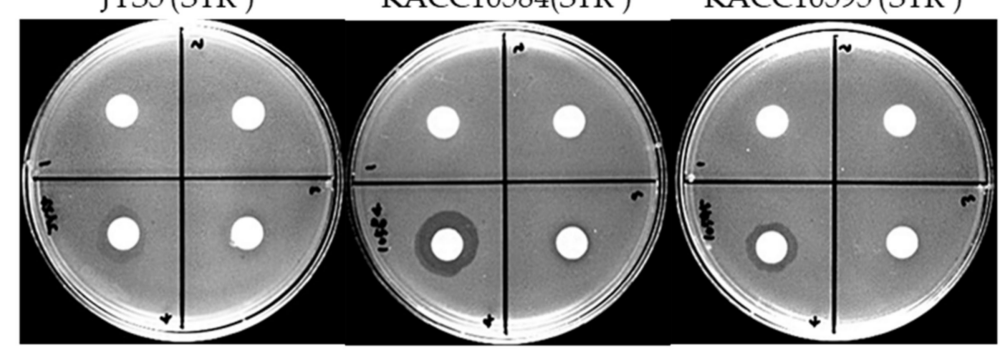

(b)

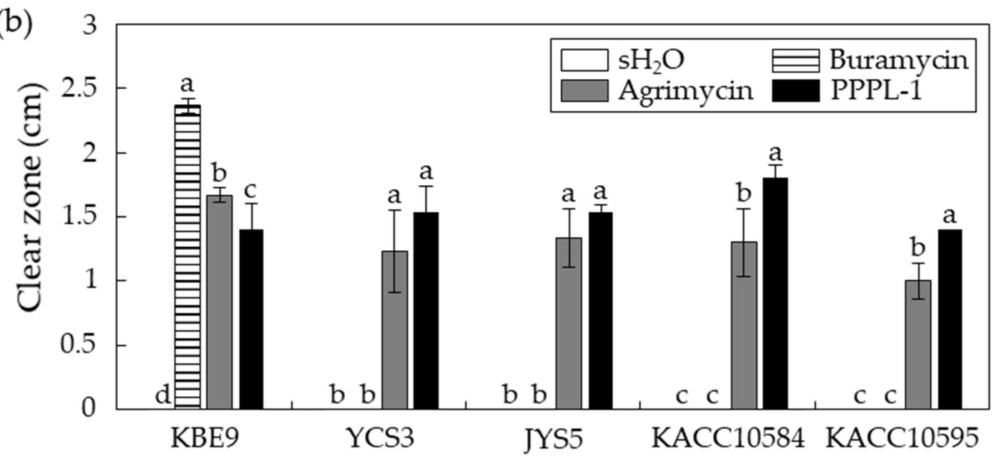

Figure 4. Antibacterial effects of PPPL-1 on streptomycin-resistant Psa isolates. (a) The images of plates showing clear zones. The most top left figure showed the treatment of other figures. (b) Length of clear zone caused by each treatment. The error bars indicate the standard deviation $(n=3)$, and the alphabets on top of each bar indicate the different groups based on significant differences at $p<0.05$ by Duncan's multiple range test in each strain. $\mathrm{sH}_{2} \mathrm{O}$, sterilized water; Buramycin ${ }^{\mathrm{TM}}$ $(1.25 \mathrm{~g} / \mathrm{L}) ;$ Agrimycin $^{\mathrm{TM}}(0.4 \mathrm{~g} / \mathrm{L})$; PPPL-1 $\left(10^{8} \mathrm{pfu} / \mathrm{mL}\right)$. 


\subsection{Stability of PPPL-1 Phage in the Field Soil and Low Temperature}

In the previous report, we showed that the lytic activity of PPPL-1 phage is stable under the field temperature (average temperature in kiwifruit-growing regions in Korea over the year: 0 to $26{ }^{\circ} \mathrm{C}$ ) and $\mathrm{pH} 4-11$ [39]. However, here, we checked how long the lytic activity of PPPL-1 phage can be sustained in the field soil at $26^{\circ} \mathrm{C}$. First, to check the viability of PPPL-1 phage inside the field soil, $10^{8} \mathrm{pfu} / \mathrm{mL}$ of PPPL-1 phage was inoculated in the field soil collected from the kiwifruit orchard in Korea. The PPPL-1 phage kept its lytic activity against Psa for more than $240 \mathrm{~h}$ in the field soil at $26^{\circ} \mathrm{C}$ (Figure 5a). For long-term storage, whether the lytic activity of PPPL-1 phage can be kept stable at lowtemperature $\left(0 \pm 2{ }^{\circ} \mathrm{C}\right)$ or not is critical. Therefore, about $2 \times 10^{10} \mathrm{pfu} / \mathrm{mL}$ of PPPL-1 phage solution as the initial titer was kept at this temperature. The data shows that PPPL-1 phage was very stable for more than 7 days at low temperature (Figure $5 b$ ). These results indicate that PPPL-1 phage can be used in the field where kiwifruit trees are growing and can be kept at low temperature for storage.

(a)

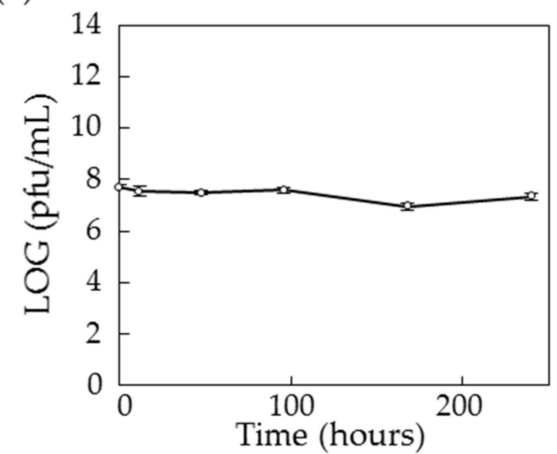

(b)

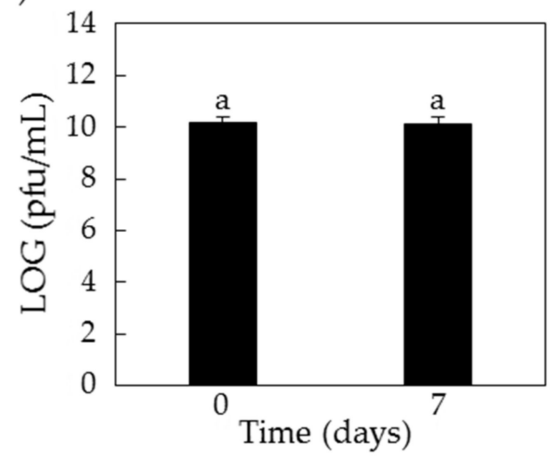

(c)

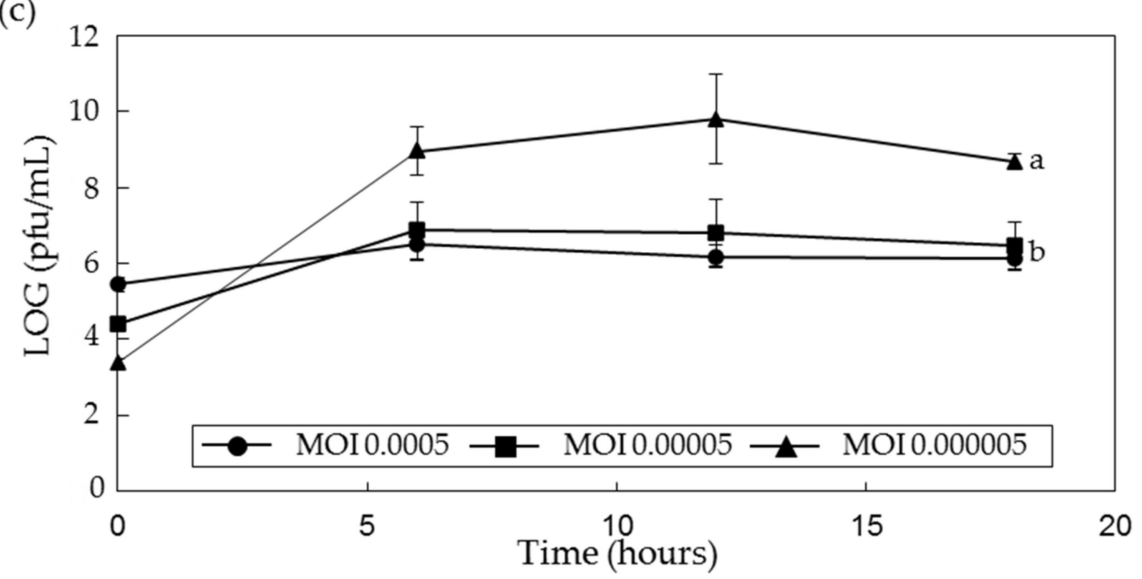

Figure 5. Stability of PPPL-1 phage in the field soil at $26{ }^{\circ} \mathrm{C}$ (a) and low temperature $\left(0-2{ }^{\circ} \mathrm{C}\right)$ (b) and also minimum MOI for scaled-up production (c). The phages of $10^{8} \mathrm{pfu} / \mathrm{mL}$ for (a) and $10^{10} \mathrm{pfu} / \mathrm{mL}$ for $(\mathbf{b})$ were used for assays. The phage was incubated with host bacteria $\left(\mathrm{OD}_{600}=0.5\right)$ at three different MOIs, and the phage concentration was measured at the indicated time points (c). Error bars indicate standard deviations of three replicates $(n=3)$, and the alphabets on the top of error bars (a) or in the next lines (b) indicate the different groups based on significant differences at $p<0.05$ by Duncan's multiple range test.

\subsection{Optimal Conditions for Scaled-Up Production of PPPL-1 Phage}

The optimal conditions for scaled-up production of PPPL-1 phage need to be determined, and we tested different parameters to optimize phage titers. Two of critical conditions for efficient massive production of the phage are the optimal stage or concentration of host bacteria and the minimum MOI. First, we checked the optimal bacterial 
stage for efficient phage production with MOI 0.1. The data highlighted that 0.5 of $\mathrm{OD}_{600}$ (approximately $5 \times 10^{8} \mathrm{cfu} / \mathrm{mL}$ ) was more efficient than 0.2 or 1.0 of $\mathrm{OD}_{600}$ (data now shown). Next, we checked the minimum MOI with 0.5 of $\mathrm{OD}_{600}$ of host bacteria. For this, we set up three different MOIs, MOI 0.0005, 0.00005, and 0.000005, and checked phage titers at several time points. The phage titer in all three MOIs increased during the first $6 \mathrm{~h}$ after inoculation of PPPL-1 phage (Figure $5 \mathrm{c}$ ). However, only the phage titer in MOI 0.000005 increased more until $12 \mathrm{~h}$ after inoculation, and it reached to the highest amount (Figure 5c). These results indicate that MOI 0.000005 with $\mathrm{OD}_{600} 0.5$ of host bacteria in liquid medium is optimal for scaling up production of PPPL-1 phage.

\section{Discussion}

Bacterial canker caused by Psa is a destructive disease of kiwifruit and further causes serious economic loss of kiwifruit production worldwide [41]. Recently, a series of papers about the practical bacterial disease control with Pseudomonas phage have been published. However, these studies focus on demonstrating phage activity in vitro, while a few studies to date have previously investigated phage activity both in vitro and ex vivo [38,42]. One of the challenges in biocontrol with phages is the incompatibility of phage efficacy under in vitro and in vivo conditions [33]. However, in this study, we demonstrate the efficacy of PPPL-1 phage in suppressing canker disease in vivo.

The results of PPPL-1 application in kiwifruit plants before Psa infection under greenhouse conditions demonstrated disease suppression as effective as Agrimycin ${ }^{\mathrm{TM}}-\mathrm{a}$ commercial antibiotic-based product (Figures 1 and 2). Thus, this phage might be a promising biological agent for control of bacterial canker disease. However, when the phage was applied after Psa infection, it was unable to suppress disease development (Figure 3b). Unlike our results, the application of a phage cocktail with four phages, CHF1, CHF7, CHF9, and CHF21, in 2-year-old kiwifruit plants (cv. 'Hayward') $1 \mathrm{~h}$ post infection with Psa significantly suppressed both bacterial growth and disease development after 30 days [42]. The MOI used in this study was 10, which was 10- or 100-fold more than those in our study. Moreover, Psa titer was 100-fold less than that of our study. The usage of higher concentration of phages and less titer of Psa in the in vivo experiment might result in significant control efficacy. Therefore, we suggest applying this phage early spring before the disease is occurred and should not be used after pathogen infects kiwifruit trees in the field orchards. The timing to apply chemical products for control of bacterial canker in field is very critical [43].

The application of phages in field faces with different challenges such as tolerance to environmental conditions [33]. PPPL-1 phage is stable by the way it is treated or under the environment in kiwifruit cultivation regions [39]. This previous study showed that PPPL-1 phage was demonstrated to be stable up to $40^{\circ} \mathrm{C}$, at $\mathrm{pH}$ range of 3-11, and under UV-A. Furthermore, in this study, we showed its longevity in the orchard soil at $26^{\circ} \mathrm{C}$ and its stability at low temperature (Figure 5). Our results together with the previous studies support the potential of PPPL-1 phage for bacterial canker control in field where kiwifruit trees are growing. The stability of phages at natural environment in crop-growing regions is one of critical factors for good control efficacy against bacterial diseases. There are many cases where phages are stable in the crop-growing conditions in field [42,44,45].

Currently, phage cocktail has emerged as a solution to overcome the limitation of single phage treatment [33]. Wang et al. [46] explained three different ways that the phage cocktail decreased the bacterial wilt incidence in tomato including (1) individually infecting and killing target bacteria, thus reducing the pathogen density, (2) the slow development of pathogen strains via enforcing phage-resistant development, or (3) encouraging the development of antagonistic bacterial species. Furthermore, to use phage cocktail may slow down the appearance of resistant pathogens if phages in phage cocktail are genetically and morphologically different. Our phage cocktail, KHU $\varphi 34$, KHU $\varphi 38$, and PPPL-1, could suppress disease by the mixed Psa infection and showed no statistical difference with PPPL-1 treatment alone in suppressing disease (Figure 3). Therefore, it was failed to see the 
advantage of phage cocktail for disease control in this study, probably because the treatment with a single phage, PPPL-1, was so efficient. However, at least, there was no negative effects of three phage cocktail in kiwifruit leaves. Because biovar 2 and 3 of Psa are present in Korea and also there is possibility of appearance of resistant pathogen variants against PPPL-1 phage, the phage cocktail mixture should be considered for long-term treatment.

Traditionally, antibiotics have been used to control pathogenic bacteria in not only agriculture but also food processing and human therapy. However, the risk of appearance of antibiotic-resistant pathogens was warned. In the case of bacterial canker disease, streptomycin-based pesticides have been used to control Psa, and streptomycin-resistant strains were also reported [29]. PPPL-1 phage successfully inhibited the growth of several streptomycin-resistant Psa strains isolated in South Korea, compared to two streptomycinbased pesticides-Buramycin ${ }^{\mathrm{TM}}$ or Agrimycin ${ }^{\mathrm{TM}}$ (Figure 3). Thus, PPPL-1 phage might be used for controlling streptomycin-resistant Psa strains. Furthermore, the combination of PPPL-1 with antibiotics-based pesticides might also enhance the control efficacy of the current antibiotic application only and also reduce the usage of antibiotics-based pesticides. However, further experiments are needed to confirm these possibilities.

Although so many papers demonstrated the efficacy of phages in plant disease control, there are only a few commercial phage-based products such as AgriPhage ${ }^{\mathrm{TM}}$, Erwiphage, and Biolyses available worldwide [33]. To determine the best condition for processing of phage products, the concentration of host bacteria and the minimum MOI should be considered and selected. In this study, 0.5 of $\mathrm{OD}_{600}$ of host bacteria and MOI of 0.000005 were shown to be the suitable condition for scaled-up production. The relative high cost of phage application compared to the conventional methods is generally originated from the scaled-up production step, and this leads to the difficulty in phage therapy in field conditions [47]. However, the rapid increase in PPPL-1 concentration up to approximately $10^{10} \mathrm{pfu} / \mathrm{mL}$ within $12 \mathrm{~h}$ might be suitable for scaled-up production within short-term period, thus contributing to the price reduction. These features of PPPL-1 phage will be very useful to make a phage product for commercialization.

\section{Materials and Methods}

\subsection{Growth Conditions of Bacterial Strains}

Six Psa strains including KBE9, SYS1, KACC10584, and KACC10595, isolated from A. chinensis cultivar (cv.); 'Hort16A' in South Korea; and JYS5 and YCS3 isolated from A. deliciosa cv. 'Hayward' in South Korea [4] were used in this study. All strains corresponded to biovar 2 except SYS1 (biovar 3). For experimental purpose, a single colony of each strain on Tryptic Soy broth Agar (TSA; Difco, Franklin Lakes, NJ, USA) plate was used for culturing it in $5 \mathrm{~mL}$ of liquid Tryptic Soy Broth (TSB; Difco, Franklin Lakes, NJ, USA) in a shaking incubator at $140 \mathrm{rpm}$ and $26^{\circ} \mathrm{C}$ for $18 \mathrm{~h}$. The streptomycin-resistant strains (JYS5, YCS3, KACC10584, and KACC10595; [29]) were cultured on media with $50 \mu \mathrm{g} / \mathrm{mL}$ of streptomycin (Duchefa Biochemie, RV Haarlem, The Netherlands).

\subsection{Phage Lysate Preparation}

The phages PPPL-1, KHU $\varphi 34$, and $\mathrm{KHU} \varphi 38$ [37,39] were stored in sodium chloridemagnesium sulfate (SM) buffer (50 mM Tris- $\mathrm{HCl}, 100 \mathrm{mM} \mathrm{NaCl}$, and $10 \mathrm{mM} \mathrm{MgSO} 4 \cdot 7 \mathrm{H}_{2} \mathrm{O}$ ) at $4{ }^{\circ} \mathrm{C}$ for routine use and at $-80{ }^{\circ} \mathrm{C}$ by glycerol stock for long-term storage. A single plaque of each phage was collected by recovery from glycerol stock using the previously described methods of plaque assays [48] and then resuspended in SM buffer. Briefly, the phage stock solution was inoculated to melted $5 \mathrm{~mL}$ TSA containing $0.4 \%$ agar $\left(\sim 42{ }^{\circ} \mathrm{C}\right)$ and $100 \mu \mathrm{L}$ of the bacterial suspension and then poured on TSA solid plate and incubated at $26{ }^{\circ} \mathrm{C}$ overnight after properly solidifying.

For phage lysate propagation, $100 \mu \mathrm{L}$ of plaque resuspension $\left(\sim 10^{8} \mathrm{pfu} / \mathrm{mL}\right)$ was inoculated with $5 \mathrm{~mL}$ of overnight $(18 \mathrm{~h})$ liquid culture of Psa KBE9 $\left(\mathrm{OD}_{600}=0.5-0.6\right)$ in a shaking incubator at $140 \mathrm{rpm}$ for $6 \mathrm{~h}$. Then, the lysate was collected by centrifugation for $5 \mathrm{~min}$ at $8000 \times g$ to remove the remained bacteria as well as its debris. If necessary, 
the supernatant was treated by $1 \%$ chloroform for $30 \mathrm{~min}$, and then the chloroform was removed by centrifugation for $15 \mathrm{~min}$ at $3000 \times \mathrm{g}$. Finally, the supernatant was filtered with $0.22 \mu \mathrm{m}$ pore size of PVDF syringe filter (Futecs, Deajeon, Korea) and stored in $4{ }^{\circ} \mathrm{C}$. To determine the phage lysate concentration, its 10-fold diluted series was dotted on the soft TSA (0.4\% agar) plate inoculated with $100 \mu \mathrm{L}$ of Psa KBE9 $\left(\mathrm{OD}_{600}=0.5-0.6\right)$. Its concentration was calculated by counting the number of plaques formed in the dotted area.

\subsection{Scaled-Up Production and Precipitation of Phages}

To determine the optimal stage of host bacteria for scaled production, the overnight culture of Psa strain KBE9 was diluted 1000-fold in $400 \mathrm{~mL}$ liquid medium, and they were grown up to $0.2\left(\sim 2 \times 10^{8} \mathrm{cfu} / \mathrm{mL}\right), 0.5\left(\sim 5 \times 10^{8} \mathrm{cfu} / \mathrm{mL}\right)$, and $1.0\left(\sim 10^{9} \mathrm{cfu} / \mathrm{mL}\right)$ of optical density at $600 \mathrm{~nm}\left(\mathrm{OD}_{600}\right)$. Then, the PPPL-1 phage for multiplicity of infection (MOI) 0.1 was added to the bacterial suspension, and its titer was checked $12 \mathrm{~h}$ later. Next, to determine the minimum MOI for scaled-up production, $400 \mathrm{~mL}$ bacterial suspension of Psa strain KBE9 $\left(\mathrm{OD}_{600}=0.5\right)$ was inoculated with $400 \mu \mathrm{L}$ of $2.5 \times 10^{6}, 2.5 \times 10^{7}$, and $2.5 \times 10^{8} \mathrm{pfu} / \mathrm{mL}$ of the phage lysate to reach MOI $0.0005,0.00005$, and 0.000005 . After 0,6 , 12 , and $18 \mathrm{~h}$ of shaking incubation at $26^{\circ} \mathrm{C}$, the phage lysate was collected by centrifugation at $8000 \mathrm{rpm}$ for $10 \mathrm{~min}$ and filtration using filter system $(0.22 \mu \mathrm{m}$; Corning, NY, USA) with vacuum pump system, and the phage titer was calculated by the plaque assay method.

To get higher phage titer, the phage lysate was precipitated using $10 \%$ polyethylene glycol 6000 (Daejung Chemical \& metals, Siheung, Korea) supplemented with $1 \mathrm{M} \mathrm{NaCl}$ (LPS solution, Daejeon, Korea) as final concentrations. After overnight incubation at $4{ }^{\circ} \mathrm{C}$, the pellets were collected by centrifugation at $4{ }^{\circ} \mathrm{C}$ and $9000 \times g$ for $20 \mathrm{~min}$ and then resuspended with $2 \mathrm{~mL}$ of SM buffer. Finally, $0.1 \mathrm{M} \mathrm{KCl}$ was added to the suspension for well separation of phages from the pellets, and the suspension was centrifuged at $12,000 \times g$ and $4{ }^{\circ} \mathrm{C}$ for $10 \mathrm{~min}$.

\subsection{Control Efficacy Test of PPPL-1 Phage In Vivo}

The grafted kiwifruit plants with $A$. chinensis cv. 'Haehyang' (originated from the highly susceptible cv. 'Hongyang' [3]) as scion and A. deliciosa cv. 'Hayward' as rootstock were planted in $6 \mathrm{~L}$ pots in the greenhouse $\left(15-25^{\circ} \mathrm{C}\right)$ for 6 weeks. For evaluating the control efficacy of PPPL-1 phage in vivo, 12 leaves (about $15 \mathrm{~cm}$ in diameter) of 5 plants were treated with phage resuspension $\left(10^{8} \mathrm{pfu} / \mathrm{mL}\right)$ on both sides using the silicon brusher. After $2 \mathrm{~h}$, the bacteria suspension $\left(\mathrm{OD}_{600}=0.1, \sim 10^{8} \mathrm{cfu} / \mathrm{mL}\right)$ of Psa KBE9 and SYS1 mixture in sterilized tap water $(10 \mathrm{mM} \mathrm{MgCl} 2$ buffer was not used because it caused necrosis in kiwifruit leaves) was treated using the same method. For positive control, leaves were treated with Agrimycin ${ }^{\mathrm{TM}}$ (0.4 g/L, SUNGBO Chemicals, Seoul, Korea), and sterilized tap water was used as mock treatment. Moreover, the control efficacy of PPPL-1 phage was compared to the individual $\mathrm{KHU} \varphi 34$ and $\mathrm{KHU} \varphi 38$ phages [38] and also to phage cocktail with all three phages. For phage cocktail, the same amount of each phage was mixed to reach the final concentration of each phage to $10^{8} \mathrm{pfu} / \mathrm{mL}$. To enhance the attachment of treated phage and bacterial cells, 0.02\% Silwet L-77 (Momentive, NY, USA) as final concentration was added to all treatments. The treated leaves were observed for 2 weeks, and the number of leaf spots were counted to evaluate the control efficacy.

To optimize the amount of PPPL- 1 phage for treatment, two phage concentrations $\left(10^{7}\right.$ and $10^{8} \mathrm{pfu} / \mathrm{mL}$ ) were examined in 20 leaves of 5 plants at $2 \mathrm{~h}$ before or after inoculation of Psa KBE9. The experiments were performed, as described above. The treated plants were observed for 5 weeks or 7 days.

\subsection{Antibacterial Effect of PPPL-1 Phage by Filter Paper Disc Method In Vitro}

The antibacterial activity of PPPL-1 phage was tested for comparison with recommended pesticides against streptomycin-resistant Psa using disc diffusion test. Briefly, the sterilized filter paper discs (Ø8 mm; Advantech, Taipei, Taiwan) were placed on TSA plates incubated with $5 \mathrm{~mL}$ of melting soft agar and $100 \mu \mathrm{L}$ of either Psa KBE9 suspension 
$\left(\mathrm{OD}_{600}=0.5\right)$ or streptomycin-resistant Psa strains such as YCS3, JYS5, KACC10584, and KACC10595. After completely solidifying, $40 \mu \mathrm{L}$ of Buramycin ${ }^{\mathrm{TM}}$ (1.25 g/L; Farm Hannong, Seoul, Korea), Agrimycin ${ }^{\mathrm{TM}}(0.4 \mathrm{~g} / \mathrm{L})$ or PPPL-1 $\left(10^{8} \mathrm{pfu} / \mathrm{mL}\right)$ was dropped onto each disc. After complete drying, each plate was sealed and incubated at $26^{\circ} \mathrm{C}$. The diameter $(\mathrm{cm})$ of clear zones was measured as the indication of antibacterial activity.

\subsection{Stability Test of PPPL-1 Phage in the Field Soil and Low Temperature}

For stability test in soil, $10^{8} \mathrm{pfu} / \mathrm{g}$ of PPPL-1 phage was inoculated to the field soil collected from kiwifruit orchard and then incubated at $26{ }^{\circ} \mathrm{C}$. The live phage titer was determined at $0,1,2,4$, and 7 days after inoculation using plaque assay against Psa strain KBE9. For stability at low temperature, $1 \mathrm{~mL}$ phage suspension $\left(\sim 10^{10} \mathrm{pfu} / \mathrm{mL}\right)$ was kept at $0-2{ }^{\circ} \mathrm{C}$, and the live phage titer was measured at 7 days after incubation.

\subsection{Statistical Analysis}

To statistically analyze all results, Duncan's multiple range test $(p<0.05)$ was performed with SAS (version 9.4 for Windows; SAS Institute, Cary, NC, USA). All experiments were repeated more than twice using three or more plants in each assay.

Author Contributions: Y.-R.S., N.T.V., J.P., I.S.H., H.-J.J., Y.-S.C., and C.-S.O. designed and performed experiments. Y.-R.S., N.T.V., and C.-S.O. wrote a paper. All authors reviewed and approved the final version of the manuscript.

Funding: This work was carried out with the support of Korea Institute of Planning and Evaluation for Technology in Food, Agriculture, Forestry (IPET) through Agri-Bio industry Technology Development Program, funded by Ministry of Agriculture, Food and Rural Affairs (MAFRA) (No. 317012-4 and No. 320041051HD020).

Institutional Review Board Statement: Not applicable.

Informed Consent Statement: Not applicable.

Data Availability Statement: All data are contained within the article.

Acknowledgments: We thank Young Jin Koh and Korean Agricultural Culture Collection for providing Psa strains.

Conflicts of Interest: The authors declare that they have no conflict of interest.

\section{References}

1. Ferrante, P.; Scortichini, M. Identification of Pseudomonas syringae pv. actinidiae as causal agent of bacterial canker of yellow kiwifruit (Actinidia chinensis Planchon) in central Italy. J. Phytopathol. 2009, 157, 768-770. [CrossRef]

2. McCann, H.C.; Li, L.; Liu, Y.; Li, D.; Pan, H.; Zhong, C.; Rikkerink, E.H.; Templeton, M.D.; Straub, C.; Colombi, E. Origin and evolution of the kiwifruit canker pandemic. Genome Biol. Evol. 2017, 9, 932-944.

3. Wang, F.; Li, J.; Ye, K.; Liu, P.; Gong, H.; Jiang, Q.; Qi, B.; Mo, Q. An in vitro Actinidia bioassay to evaluate the resistance to Pseudomonas syringae pv. actinidiae. Plant Pathol. J. 2019, 35, 372. [CrossRef]

4. Koh, Y.; Kim, G.; Jung, J.; Lee, Y.; Hur, J. Outbreak of bacterial canker on Hort16A (Actinidia chinensis Planchon) caused by Pseudomonas syringae pv. actinidiae in Korea. N. Z. J. Crop Hortic. Sci. 2010, 38, 275-282. [CrossRef]

5. Donati, I.; Buriani, G.; Cellini, A.; Mauri, S.; Costa, G.; Spinelli, F. New insights on the bacterial canker of kiwifruit (Pseudomonas syringae pv. actinidiae). J. Berry Res. 2014, 4, 53-67. [CrossRef]

6. Vanneste, J.L. The scientific, economic, and social impacts of the New Zealand outbreak of bacterial canker of kiwifruit (Pseudomonas syringae pv. actinidiae). Annu. Rev. Phytopathol. 2017, 55, 377-399. [CrossRef]

7. Young, J. Pseudomonas syringae pv. actinidiae in New Zealand. J. Plant Pathol. 2012, 94, S1.5-S1.10.

8. Qin, H.; Gao, X.; Zhao, Z.; Zhu, S.; Li, J.; Huang, L. The prevalence dynamics and rules of bacterial canker of kiwi fruit in Shaanxi. Acta Phytophylacica Sin. 2013, 40, 225-230.

9. Donati, I.; Cellini, A.; Sangiorgio, D.; Vanneste, J.L.; Scortichini, M.; Balestra, G.M.; Spinelli, F. Pseudomonas syringae pv. actinidiae: Ecology, infection dynamics and disease epidemiology. Microb. Ecol. 2020, 80, 81-102. [CrossRef] [PubMed]

10. Guroo, I.; Wani, S.; Wani, S.; Ahmad, M.; Mir, S.; Masoodi, F. A review of production and processing of kiwifruit. Int. J. Food Process. Technol. 2017, 8, 699-705.

11. Takikawa, Y.; Serizawa, S.; Ichikawa, T.; Tsuyumu, S.; Goto, M. Pseudomonas syringae pv. actinidiae pv. nov. the causal bacterium of canker of kiwifruit in Japan. Jpn. J. Phytopathol. 1989, 55, 437-444. [CrossRef] 
12. Koh, Y.; Park, S.; Lee, D. Characteristics of bacterial canker of kiwifruit occurring in Korea and its control by trunk injection. Korean J. Plant Pathol. 1996, 12, 324-330.

13. Balestra, G.; Renzi, M.; Mazzaglia, A. First report of bacterial canker of Actinidia deliciosa caused by Pseudomonas syringae pv. actinidiae in Portugal. New Dis. Rep. 2010, 22, 10. [CrossRef]

14. Balestra, G.; Renzi, M.; Mazzaglia, A. First report of Pseudomonas syringae pv. actinidiae on kiwifruit plants in Spain. N. Dis. Rep. 2011, 24, 10. [CrossRef]

15. Vanneste, J.; Poliakoff, F.; Audusseau, C.; Cornish, D.; Paillard, S.; Rivoal, C.; Yu, J. First report of Pseudomonas syringae pv. actinidiae, the causal agent of bacterial canker of kiwifruit in France. Plant Dis. 2011, 95, 1311. [CrossRef]

16. Bastas, K.; Karakaya, A. First report of bacterial canker of kiwifruit caused by Pseudomonas syringae pv. actinidiae in Turkey. Plant Dis. 2012, 96, 452. [CrossRef]

17. Dreo, T.; Pirc, M.; Ravnikar, M.; Žežlina, I.; Poliakoff, F.; Rivoal, C.; Nice, F.; Cunty, A. First report of Pseudomonas syringae pv. actinidiae, the causal agent of bacterial canker of kiwifruit in Slovenia. Plant Dis. 2014, 98, 1578. [CrossRef]

18. Holeva, M.; Glynos, P.; Karafla, C. First report of bacterial canker of kiwifruit caused by Pseudomonas syringae pv. actinidiae in Greece. Plant Dis. 2015, 99, 723. [CrossRef]

19. Meparishvili, G.; Gorgiladze, L.; Sikharulidze, Z.; Muradashvili, M.; Koiava, L.; Dumbadze, R.; Jabnidze, N. First report of bacterial canker of kiwifruit caused by Pseudomonas syringae pv. actinidiae in Georgia. Plant Dis. 2016, 100, 517. [CrossRef]

20. Sawada, H.; Kondo, K.; Nakaune, R. Novel biovar (biovar 6) of Pseudomonas syringae pv. actinidiae causing bacterial canker of kiwifruit (Actinidia deliciosa) in Japan. Jpn. J. Phytopathol. 2016, 82, 101-115. [CrossRef]

21. Cunty, A.; Poliakoff, F.; Rivoal, C.; Cesbron, S.; Fischer-Le Saux, M.; Lemaire, C.; Jacques, M.; Manceau, C.; Vanneste, J. Characterisation of Pseudomonas syringae pv. actinidiae (Psa) isolated from France and assignment of strains Psa biovar 4 to a de novo pathovar: Pseudomonas syringae pv. actinidifoliorum pv. nov. Plant Pathol. 2015, 64, 582-596. [CrossRef]

22. Koh, Y.J.; Kim, G.H.; Koh, H.S.; Lee, Y.S.; Kim, S.-C.; Jung, J.S. Occurrence of a new type of Pseudomonas syringae pv. actinidiae strain of bacterial canker on kiwifruit in Korea. Plant Pathol. J. 2012, 28, 423-427. [CrossRef]

23. Mazzaglia, A.; Studholme, D.J.; Taratufolo, M.C.; Cai, R.; Almeida, N.F.; Goodman, T.; Guttman, D.S.; Vinatzer, B.A.; Balestra, G.M. Pseudomonas syringae pv. actinidiae (PSA) isolates from recent bacterial canker of kiwifruit outbreaks belong to the same genetic lineage. PLoS ONE 2012, 7, e36518. [CrossRef] [PubMed]

24. Butler, M.I.; Stockwell, P.A.; Black, M.A.; Day, R.C.; Lamont, I.L.; Poulter, R.T. Pseudomonas syringae pv. actinidiae from recent outbreaks of kiwifruit bacterial canker belong to different clones that originated in China. PLoS ONE 2013, 8, e57464.

25. McCann, H.C.; Rikkerink, E.H.; Bertels, F.; Fiers, M.; Lu, A.; Rees-George, J.; Andersen, M.T.; Gleave, A.P.; Haubold, B.; Wohlers, M.W. Genomic analysis of the kiwifruit pathogen Pseudomonas syringae pv. actinidiae provides insight into the origins of an emergent plant disease. PLoS Pathog. 2013, 9, e1003503. [CrossRef]

26. Cameron, A.; Sarojini, V. Pseudomonas syringae pv. actinidiae: Chemical control, resistance mechanisms and possible alternatives. Plant Pathol. 2014, 63, 1-11. [CrossRef]

27. Han, H.S.; Koh, Y.J.; Hur, J.-S.; Jung, J.S. Occurrence of the strA-strB streptomycin resistance genes in Pseudomonas species isolated from kiwifruit plants. J. Microbiol. 2004, 42, 365-368.

28. Nakajima, M.; Masao, G.; Tadaaki, H. Similarity between copper resistance genes from Pseudomonas syringae pv. actinidiae and P. syringae pv. tomato. J. Gen. Plant Pathol. 2002, 68, 68-74. [CrossRef]

29. Lee, Y.S.; Kim, G.H.; Song, Y.-R.; Oh, C.-S.; Koh, Y.J.; Jung, J.S. Streptomycin Resistant Isolates of Pseudomonas syringae pv. actinidiae in Korea. Res. Plant Dis. 2020, 26, 44-47. [CrossRef]

30. Jones, J.B.; Jackson, L.; Balogh, B.; Obradovic, A.; Iriarte, F.; Momol, M. Bacteriophages for plant disease control. Annu. Rev. Phytopathol. 2007, 45, 245-262. [CrossRef]

31. Jassim, S.A.; Limoges, R.G. Natural solution to antibiotic resistance: Bacteriophages 'The Living Drugs'. World J. Microbiol. Biotechnol. 2014, 30, 2153-2170. [CrossRef]

32. Brüssow, $\mathrm{H}$. What is needed for phage therapy to become a reality in Western medicine? Virology 2012, 434, 138-142. [CrossRef]

33. Vu, N.T.; Oh, C.-S. Bacteriophage Usage for Bacterial Disease Management and Diagnosis in Plants. Plant Pathol. J. 2020, 36, 204-217. [CrossRef]

34. Yin, Y.; Ni, P.e.; Deng, B.; Wang, S.; Xu, W.; Wang, D. Isolation and characterisation of phages against Pseudomonas syringae pv. actinidiae. Acta Agric. Scand. B Soil Plant Sci. 2019, 69, 199-208. [CrossRef]

35. Di Lallo, G.; Evangelisti, M.; Mancuso, F.; Ferrante, P.; Marcelletti, S.; Tinari, A.; Superti, F.; Migliore, L.; D’Addabbo, P.; Frezza, D. Isolation and partial characterization of bacteriophages infecting Pseudomonas syringae pv. actinidiae, causal agent of kiwifruit bacterial canker. J. Basic Microbiol. 2014, 54, 1210-1221. [CrossRef] [PubMed]

36. Frampton, R.A.; Taylor, C.; Moreno, A.V.H.; Visnovsky, S.B.; Petty, N.K.; Pitman, A.R.; Fineran, P.C. Identification of bacteriophages for biocontrol of the kiwifruit canker phytopathogen Pseudomonas syringae pv. actinidiae. Appl. Environ. Microbiol. 2014, 80, 2216-2228. [CrossRef] [PubMed]

37. Yu, J.-G.; Lim, J.-A.; Song, Y.-R.; Heu, S.; Kim, G.H.; Koh, Y.J.; Oh, C.-S. Isolation and characterization of bacteriophages against Pseudomonas syringae pv. actinidiae causing bacterial canker disease in kiwifruit. J. Microbiol. Biotechnol. 2016, 26, 385-393.

38. Pinheiro, L.A.; Pereira, C.; Barreal, M.E.; Gallego, P.P.; Balcão, V.M.; Almeida, A. Use of phage $\phi 6$ to inactivate Pseudomonas syringae pv. actinidiae in kiwifruit plants: In vitro and ex vivo experiments. Appl. Microbiol. Biotechnol. 2020, 104, 1319-1330. [CrossRef] 
39. Park, J.; Lim, J.-A.; Yu, J.-G.; Oh, C.-S. Genomic features and lytic activity of the bacteriophage PPPL-1 effective against Pseudomonas syringae pv. actinidiae, a cause of bacterial canker in kiwifruit. J. Microbiol. Biotechnol. 2018, 28, 1542-1546. [CrossRef]

40. Han, H.-S.; Nam, H.-Y.; Koh, Y.-J.; Hur, J.-S.; Jung, J.-S. Molecular bases of high-level streptomycin resistance in Pseudomonas marginalis and Pseudomonas syringae pv. actinidiae. J. Microbiol. 2003, 41, 16-21.

41. Scortichini, M.; Marcelletti, S.; Ferrante, P.; Petriccione, M.; Firrao, G. Pseudomonas syringae pv. actinidiae: A re-emerging, multi-faceted, pandemic pathogen. Mol. Plant Pathol. 2012, 13, 631-640. [CrossRef] [PubMed]

42. Flores, O.; Retamales, J.; Núñez, M.; León, M.; Salinas, P.; Besoain, X.; Yañez, C.; Bastías, R. Characterization of Bacteriophages against Pseudomonas syringae pv. actinidiae with Potential Use as Natural Antimicrobials in Kiwifruit Plants. Microorganisms 2020, 8, 974. [CrossRef]

43. Preti, M.; Scannavini, M.; Franceschelli, F.; Cavazza, F.; Antoniacci, L.; Rossi, R.; Bugiani, R.; Tommasini, M.; Collina, M. Field efficacy of some products against the bacterial canker of kiwifruit in Emilia-Romagna Region, Italy. Acta Hortic. 2015, 1243, 39-48. [CrossRef]

44. Iriarte, F.B.; Obradović, A.; Wernsing, M.H.; Jackson, L.E.; Balogh, B.; Hong, J.A.; Momol, M.T.; Jones, J.B.; Vallad, G.E. Soil-based systemic delivery and phyllosphere in vivo propagation of bacteriophages: Two possible strategies for improving bacteriophage persistence for plant disease control. Bacteriophage 2012, 2, e23530. [CrossRef] [PubMed]

45. Rombouts, S.; Volckaert, A.; Venneman, S.; Declercq, B.; Vandenheuvel, D.; Allonsius, C.N.; Van Malderghem, C.; Jang, H.B.; Briers, Y.; Noben, J.P. Characterization of novel bacteriophages for biocontrol of bacterial blight in leek caused by Pseudomonas syringae pv. porri. Front. Microbiol. 2016, 7, 279. [CrossRef]

46. Wang, X.; Wei, Z.; Yang, K.; Wang, J.; Jousset, A.; Xu, Y.; Shen, Q.; Friman, V.-P. Phage combination therapies for bacterial wilt disease in tomato. Nat. Biotechnol. 2019, 37, 1513-1520. [CrossRef]

47. Lang, J.M.; Gent, D.H.; Schwartz, H.F. Management of Xanthomonas leaf blight of onion with bacteriophages and a plant activator. Plant Dis. 2007, 91, 871-878. [CrossRef]

48. Kropinski, A.M.; Mazzocco, A.; Waddell, T.E.; Lingohr, E.; Johnson, R.P. Enumeration of bacteriophages by double agar overlay plaque assay. In Bacteriophages; Springer's Humana Press: Totowa, NJ, USA, 2009; pp. 69-76. 